\title{
Salix lapponum L. (DOWNY WILLOW) IN STANDS UNDER ANTHROPOPRESSURE IN THE ŁĘCZNA-WŁODAWA LAKELAND
}

\author{
Magdalena Pogorzelec \\ Department of General Ecology, University of Life Sciences in Lublin \\ Akademicka 13, 20-950 Lublin,Poland \\ e-mail: magdalena.pogorzelec@up.lublin.pl
}

Received: 5.10.2009

\begin{abstract}
The studies carried out in the years 2004-2005 and in 2009 were aimed at identifying the functioning conditions of a boreal plant relict, Salix lapponum, in its stands under anthropopressure in the Łęczna-Włodawa Lakeland. The study results confirmed that the number of S. lapponum stands on Lake Miejskie and on Cow Marsh and its population size had significantly decreased as well as the population condition had deteriorated during the last 50 years. Based on the results of an analysis of environmental (biocenotic and abiotic) factors it was found that changes in habitat conditions in its stands were the main threat for downy willow. Another cause of population decline and the deteriorated condition of downy willow individuals may be the habitat isolation. The observed intraspecific phenomena, i.e. the lack of flowering in individuals and the lack of downy willow seedlings could be the reason for insufficient reproduction efficiency, ipso facto, the weaker adaptation of individuals to changes in habitat condition. Therefore, it seems that it is necessary to pursue active species conservation and protection which should primarily involve population reconstruction - restitution.
\end{abstract}

Key words: Salix lapponum, peat bog, Lake Miejskie, Cow Marsh, anthropopressure

\section{INTRODUCTION}

The natural ecosystems of the Łęczna-Włodawa Lakeland are constantly subjected to anthropopressure which indisputably affects this area's natural values. Human activities, such as land drainage and irrigation, hydraulic improvements as well as agriculture and tourism, all contribute to the effects on the functioning of the entire water and peat-bog ecosystems, but also their components, like animal and plant populations.

Among particularly endangered species of bog flora, a boreal relict, Salix lapponum, should be distinguished, a species which is especially susceptible to changes in the natural water balance in its habitats. The populations of this species were characterised as numerous in many stands in the Łęczna-Włodawa Lakeland in the 1950's (Fijałkowski, 1959). Currently, there are only few isolated populations left, which are composed by a few or about a dozen individuals. The downy willow stands are known from the Polesie National Park protected areas (the peat bogs near lakes Moszne, Długie, Karaśne and the peat bog Blizionki) and from unprotected areas - the peat bogs near lakes Bikcze, Miejskie and Lubowież, Lubowieżek (on the Cow Marsh complex) (S ołtys and Różycki, 1996; Pog orzelec, 2008, 2009).

Lake Miejskie is a shallow, eutrophic water body, which does not have any natural inflow or runoff. However, this lake is connected with drainage canals which are situated near Lake Kleszczów. Lake Miejskie performs the recreation function to a greater degree than the fishery function. A young pine wood adjoins the lake from its north-western and eastern side, and from the other sides it is surrounded by a peat bog which borders directly crop fields (P o p i o łe k, 1971; Radwan and Kornijów, 1998; Sug i e r, 2002). The succession of grey willow bushes can be observed on the peat bog adjacent to the lake. This expansion is visible both deep inside the peat bog and near the lake shore. The species composition of rush and aquatic vegetation is decreasing, which is attributable to an excessive increase of water trophy (S u gi er, 2002).

The Cow Marsh (Krowie Bagno) is one of the largest peat bog complexes of the Polish part of the Polesie region. Almost half of this area is occupied by moist, extensively used or overgrowing meadows which developed on drained peat bogs in the 1960 's. Slightly less space is occupied by lowland and transitional bogs, bog springs and waterside vegetation communities. Within the boundaries of this area, 
there are four lakes: Laskie, Lubowież, Lubowieżek and Hańskie. These are overgrowing, eutrophic water bodies, surrounded by peat bogs subjected to ecological succession. The encroachment of expansive species, e.g. grey willow, common birch and common reed, has the greatest influence on changes in habitat conditions in these ecosystems is ( $\mathrm{G} \mathrm{a} \mathrm{j} \mathrm{d} \mathrm{a,} \mathrm{1997).}$

The aim of the study, conducted on the peat bog on Lake Miejskie and on Cow Marsh in the years 2004-2005 and in 2009, was to determine the location, population size and the condition of a boreal relict, S. lapponum, and to characterise selected habitat fac- tors (abiotic and biocenotic) in its stands. The study was also designed to answer the question: Do the isolated Salix lapponum populations have any chance of surviving in the habitats exposed to various forms of human interference?

\section{METHODS}

The study was carried out on the peat bog on Lake Miejskie as well as on the peat bogs surrounding Lake Lubowież and Lake Lubowieżek in the years 2004-2005 and in July 2009 (Fig. 1).

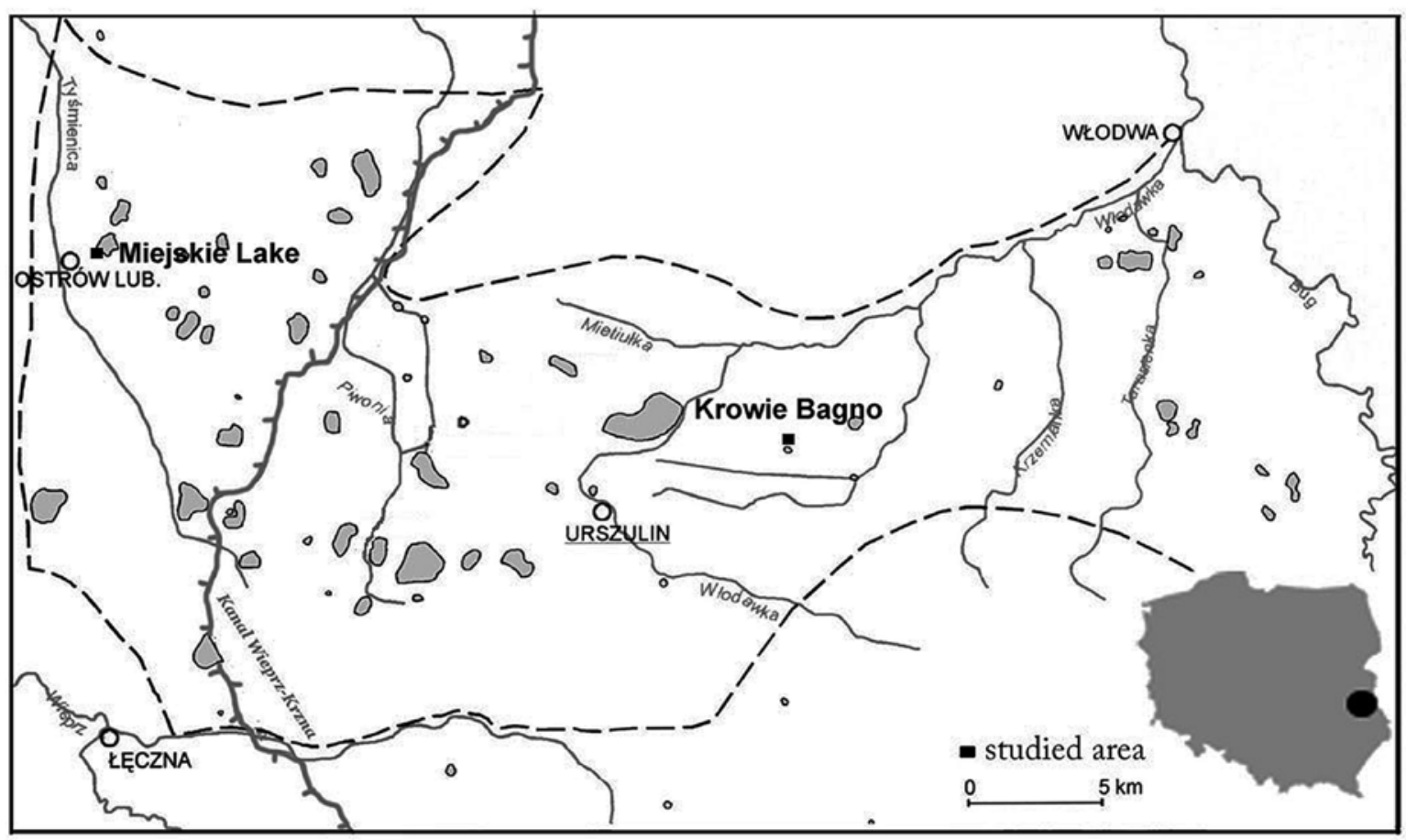

Fig. 1. Location of study area on Łęczna-Włodawa Lakeland

The first exploration on foot in this area was made in April 2004 in order to determine the location of Salix lapponum within the study area. Literature data were used to identify the sites of occurrence of the studied species (Fijałkowski, 1958, 1959; Kazimierczakowa and Zarzycki, 2001; Fijałkowski and Izdebski, 2002). In July 2004, 8 study plots were set up (with the same size of $25 \mathrm{~m}^{2}$ ): 3 plots (M1 - M3) on the peat bog adjacent to Lake Miejskie; 5 plots (L1 - L5) in the Cow Marsh area.

The number and height of Salix lapponum above-ground shoots were determined, as well as the development degree (condition) of individuals - using an original, comparative, three-level classification of shoot condition, which took into account the characteristic habit and general health condition of plants (Pogorzelec, 2009). Every above-ground stem, regardless of the underground connections, was considered as a specimen. The study was repeated in July 2009.

The groundwater level (in $\mathrm{cm}$ ) was determined in situ in each study plot, with the bog surface pressed down by human weight. The $\mathrm{pH}$ value of the highest groundwater layer was measured, using a batteryoperated field $\mathrm{pH}$-meter, as well as water electrolytic conductivity $\left(\mu \mathrm{Scm}^{-1}\right.$; using a field battery-operated conductometer). Water samples were collected for chemical laboratory analysis in order to determine the concentration of cations $\left(\mathrm{Ca}^{2+}, \mathrm{K}^{+}, \mathrm{Mg}^{2+}, \mathrm{Na}^{+}\right)$. Laboratory analysis was performed in the Central Laboratory of the University of Life Sciences in Lublin.

Species lists of the flora in phytocoenoses of the study plots were made, which included the characteristic cover-abundance of particular species. The taxa were identified following R u t k ow s k i (2001), 
whereas species nomenclature followed $\mathrm{Mirek}$ et al. (2002). During office investigations, Ecological indicator values of vascular plants of Poland ( $\mathrm{Zar} \mathrm{z} \mathrm{y} \mathrm{-}$ $\mathrm{ck} \mathrm{i}$ et al. 2002) was also used to determine specific habitat conditions, based on the affinity of plant species of particular phytocoenoses with characteristic ecological groups.

The plant material - pollen grains of Salix lapponum - was collected in April 2005 and it was used to determine its viability. Typical acetocarmine microscopic slides were made at the sampling sites using fresh pollen. Acetocarmine, which dyed the protoplast of live pollen grains red, allowed the exclusion of their sterility. The slides were analyzed using a light microscope. The percentage of live pollen grains was calculated. In order to minimize the possibility of making calculation errors, 3 slides were made from each of the 7 samples, and then 300 pollen grains were analysed in each of them.

\section{RESULTS}

During the exploration of the study area in 2004, S. lapponum stands were found on the peat bog on Lake Miejskie (3 groups of shoots at a distance > $100 \mathrm{~m}$ from each other) as well as on Lakes Lubowież and Lubowieżek (5 groups). The study repeated in 2009 confirmed the occurrence of only one group of Salix lapponum shoots on Lake Miejskie and 4 groups in the Cow Marsh area. A decrease in the numbers was found, and in the majority of cases the deteriorated condition of individuals in the studied populations was also observed (it was frequently associated with visible symptoms of pathogen activity on leaves) (Tab.1).

In the years 2004-2004, vascular plant species most frequently co-occurring with Salix lapponum in its stands on Lake Miejskie were as follows: Menyanthes trifoliata, Calla palustris, Typha angustifolia, Comarum palustre, Thelypteris palustris; and in the Cow Marsh area: Phragmites australis, Comarum palustre, Oxycoccus palustris, Salix rosmarinifolia, Thelypteris palustris (mainly species characteristic of the syntaxonomic classes Alnetea glutinosae and Phragmitetea). In 2009 the abovementioned species were confirmed in the species composition of the phytocoenoses in the Salix lapponum stands. Ecological analysis of the flora of the studied phytocoenoses ( $\mathrm{Z}$ a r z y c k i et al. 2002) demonstrated the dominance of taxa with characteristic habitat preferences. Species characteristic of soils rich in organic, eutrophic matter with the neutral or slightly acid reaction of the substrate, wet and humid habitats, made up the largest group in all the studied stands.

The habitat study showed that in the years 2004-2005 downy willow grew in stands with varying hydration. The stands located in the Cow Marsh area were characterised by a particularly low groundwater level. In the investigations conducted five years later, an insignificant rise of water level was noted in the study plots, but it did not result in improvement in the condition of the Salix lapponum population (Table 2)

In 2005 the viability of Salix lapponum pollen grains was higher than $90 \%$ in the samples (Table 3 ). In 2009, flowering of Salix lapponum was not noted in the stands where it had taken place previously.

Table 1

Salix lapponum on study plots in 2004-2005 and 2009

\begin{tabular}{|c|c|c|c|c|c|c|c|c|c|}
\hline Plots & Year & M1 & M2 & M3 & $\mathrm{L} 1$ & $\mathrm{~L} 2$ & L3 & L4 & L5 \\
\hline \multirow{2}{*}{ Number of shoots } & 2004-05 & 9 & 13 & 8 & 7 & 6 & 9 & 5 & 6 \\
\hline & 2009 & 0 & 4 & 0 & 1 & 1 & 2 & 3 & nc \\
\hline \multirow{2}{*}{ Height of shoots $(\mathrm{cm})$} & 2004-05 & $50-100$ & $60-120$ & $30-170$ & $<60$ & $<100$ & $<120$ & $<90$ & $<60$ \\
\hline & 2009 & $\mathrm{nc}$ & $50-110$ & $\mathrm{nc}$ & 100 & 90 & $<120$ & $<80$ & nc \\
\hline \multirow{2}{*}{$\begin{array}{l}\text { Distance between shoots } \\
\qquad(\mathrm{cm})\end{array}$} & 2004-05 & $<50$ & $<40$ & $<20$ & $<20$ & $<20$ & $<40$ & $<50$ & $<30$ \\
\hline & 2009 & nc & $<30$ & nc & - & - & $<40$ & $<30$ & nc \\
\hline \multirow{2}{*}{$\begin{array}{l}\text { Ratio of female to male } \\
\text { blooming shoots } \bigcirc: \bigcirc^{\nearrow}\end{array}$} & 2004-05 & $0: 1$ & $0: 1$ & $0: 1$ & - & $0: 1$ & $1: 2$ & $0: 1$ & $0: 1$ \\
\hline & 2009 & nc & nc & nc & - & - & - & - & $\mathrm{nc}$ \\
\hline \multirow{2}{*}{$\begin{array}{l}\text { Individual condition } \\
\qquad(1-3)\end{array}$} & 2004-05 & 2 & 3 & 2 & 1 & 3 & 2 & 2 & 1 \\
\hline & 2009 & nc & 2 & nc & 2 & 2 & 2 & 2 & nc \\
\hline
\end{tabular}

nc- not confirmed 
Table 2

Values of the selected abiotic environmental factors in the study plots in 2004-2005 and 2009

\begin{tabular}{|c|c|c|c|c|c|c|c|c|}
\hline \multirow[b]{2}{*}{ Plots } & \multirow[b]{2}{*}{ Year } & \multirow{2}{*}{$\begin{array}{l}\text { Level of } \\
\text { ground water } \\
(\mathrm{cm})\end{array}$} & \multirow[b]{2}{*}{ Water acidity $(\mathrm{pH})$} & \multirow{2}{*}{$\begin{array}{c}\text { Water } \\
\text { electrolytic } \\
\text { conductivity } \\
\left(\mu \mathrm{S} \mathrm{cm}^{-1}\right)\end{array}$} & \multicolumn{4}{|c|}{$\left(\mathrm{mg} \cdot \mathrm{dm}^{-3}\right)$} \\
\hline & & & & & $\mathrm{Mg}$ & $\mathrm{Na}$ & K & $\mathrm{Ca}$ \\
\hline \multirow{3}{*}{ M1 } & 2004 & 8 & 4.81 & 111.0 & - & - & - & - \\
\hline & 2005 & 4 & 3.86 & 164.0 & 7.30 & 14.70 & 5.71 & 33.41 \\
\hline & 2009 & nc & nc & $\mathrm{nc}$ & - & - & - & - \\
\hline \multirow{3}{*}{ M2 } & 2004 & 3 & 4.67 & 128.0 & - & - & - & - \\
\hline & 2005 & 2 & 4.20 & 117.0 & 3.72 & 15.24 & 8.62 & 18.82 \\
\hline & 2009 & 10 & 5.25 & 100.1 & - & - & - & - \\
\hline \multirow{3}{*}{ M3 } & 2004 & 2 & 5.34 & 98.2 & - & - & - & - \\
\hline & 2005 & 2 & 4.47 & 169.0 & 2.75 & 11.57 & 11.58 & 16.57 \\
\hline & 2009 & $\mathrm{nc}$ & $\mathrm{nc}$ & $\mathrm{nc}$ & - & - & - & - \\
\hline \multirow{3}{*}{ L1 } & 2004 & 0 & - & - & - & - & - & - \\
\hline & 2005 & 1 & 4.30 & 175.0 & 2.55 & 3.68 & 14.02 & 27.35 \\
\hline & 2009 & 5 & 6.10 & 72.0 & - & - & - & - \\
\hline \multirow{3}{*}{ L2 } & 2004 & 0 & - & - & - & - & - & - \\
\hline & 2005 & 2 & 4.40 & 185.0 & 2.68 & 2.56 & 7.47 & 27.30 \\
\hline & 2009 & 2 & 5.96 & 85.0 & - & - & - & - \\
\hline \multirow{3}{*}{ L3 } & 2004 & 0 & - & - & - & - & - & - \\
\hline & 2005 & 1 & 4.11 & 430.0 & 4.36 & 9.94 & 28.25 & 29.98 \\
\hline & 2009 & 5 & 6.03 & 67.9 & - & - & - & - \\
\hline \multirow{3}{*}{ L4 } & 2004 & 2 & 3.69 & 309.0 & - & - & - & - \\
\hline & 2005 & 2 & 4.45 & 123.0 & 2.89 & 2.76 & 13.46 & 18.91 \\
\hline & 2009 & - & 5.52 & 82.2 & - & - & - & - \\
\hline \multirow{3}{*}{ L5 } & 2004 & 0 & - & - & - & - & - & - \\
\hline & 2005 & 1 & 4.09 & 300.0 & 5.13 & 3.31 & 17.23 & 26.83 \\
\hline & 2009 & $\mathrm{nc}$ & $\mathrm{nc}$ & $\mathrm{nc}$ & - & - & - & - \\
\hline
\end{tabular}

nc - not confirmed

Table 3

Percentage of alive and dead pollen grains in fresh pollen from Salix lapponum blooming shoots on the study plots in 2005

\begin{tabular}{|c|c|c|c|c|}
\hline \multirow{2}{*}{ Plots } & \multirow{2}{*}{ Pollen grains } & \multicolumn{3}{|c|}{ Repetitions } \\
\hline & & 1 & 2 & 3 \\
\hline \multirow{2}{*}{ M1 } & Alive & 94 & 97 & 95 \\
\hline & Dead & 6 & 3 & 5 \\
\hline \multirow{2}{*}{ M2 } & Alive & 92 & 96 & 99 \\
\hline & Dead & 8 & 4 & 1 \\
\hline \multirow{2}{*}{ M3 } & Alive & 92 & 94 & 98 \\
\hline & Dead & 8 & 6 & 2 \\
\hline \multirow{2}{*}{ L2 } & Alive & 90 & 95 & 92 \\
\hline & Dead & 10 & 5 & 8 \\
\hline \multirow{2}{*}{ L3 } & Alive & 89 & 94 & 90 \\
\hline & Dead & 11 & 6 & 10 \\
\hline \multirow{2}{*}{ L4 } & Alive & 96 & 96 & 95 \\
\hline & Dead & 4 & 4 & 5 \\
\hline \multirow{2}{*}{ L5 } & Alive & 99 & 98 & 100 \\
\hline & Dead & 1 & 2 & 0 \\
\hline
\end{tabular}




\section{DISCUSSION}

Already in the 50's, Lake Miejskie was surrounded by crop fields with sandy soil almost along its entire circumference. A transitional bog formed a boundary between agriculturally used land and the lake water table. On the western shore of the lake, where the bog was not strongly grazed, Fijałkowski noted, right by the water, the occurrence of over a dozen large Salix lapponum shrubs, reaching a height of up to $1.5 \mathrm{~m}$. Less luxuriant specimens grew individually on the vast peat bog adjoining the north-western part of the lake. Fijałkowski wrote that the downy willow population was in a very good condition. Characterising the habitat conditions in its stand, he examined the groundwater level $(20 \mathrm{~cm})$ and soil $\mathrm{pH}(\mathrm{pH} 6.0)(\mathrm{Fi} \mathrm{j} \mathrm{a} 1$ kowski, 1958, 1959).

In the 1990's, the occurrence of S. lapponum in this area was confirmed by S u gi e r (2002), who included the studied species in the floristic lists of the peat bog area on Lake Miejskie.

The studies conducted in the years 2004-2005 and in 2009 indicated a reduction in population size of downy willow in the studied area over a period of 50 years, but also within the last 5 years. These observations also confirm the deteriorated condition of downy willow individuals.

The observed phenomena can be caused by two factors: the habitat and/or population factor. The changes which had taken place in the habitat manifested themselves primarily in the lowered groundwater level and the decreased value of substrate $\mathrm{pH}$ in the downy willow stands on Lake Miejskie. Such a state of affairs is probably attributable to anthropopressure factors active within the whole region, among which the activities of the Wieprz-Krzna Canal as well as pressure of agriculture and tourism should be mentioned. Additionally, on the peat bog on Lake Miejskie the ongoing destruction of the flora is taking place by the creation of illegal fishing grounds and paths used by anglers to move around.

Another reason for shrinking population resources and the deteriorated condition of individuals can be their isolation, which has taken place from the time of transformations of the natural environment of the Łęczna-Włodawa Lakeland (W i $1 \mathrm{~g}$ a t, 1991; R a d w a n, 1994). The observed interpopulation phenomena, i.e. the lack of flowering of individuals and the lack of downy willow seedlings, in the stands both on Lake Miejskie and the Cow Marsh, can be the reason for insufficient reproduction efficiency, and what follows, the weaker adaptation of individuals to changes in habitat conditions. However, the results of studies conducted in Great Britain, including Scotland, are known; they confirmed large interpopulation variation of S. lapponum, in spite of the absence of data confirming flowering or seed germination of its individuals (S t a m at i et al. 2003; 2007). But the studied populations were very numerous; hence, the conclusions arising from the study results cannot be accepted as a rule for the population of the Łęczna-Włodawa Lakeland.

In the paper by Fijałk ow ski $(1958,1959)$, we also find data on the occurrence of $S$. lapponum on the peat bog adjacent to Lake Lubowież. An analysis of the species distribution map shows that in the 1950 's the occurrence of downy willow in clusters of up to 10 shrubs was recorded there.

The stand located in the vicinity of Lake Lubowież was also confirmed during the study conducted in the years 2004-2005. The downy willow population was sparse, but the condition of individuals was very good (still in 2005 flowering of male and female individuals was observed). The structure and species composition of vegetation of the peat bog on Lake Lubowież did not change significantly over a period of 50 years, which seems to prove the slow pace of habitat transformations.

In the 1950's, other stands of the investigated species were known in the Cow Marsh area (in its western and eastern part - in the area of Lake Laskie, Fijałkowski, 1958). In the stand on the Cow Marsh, described by Fijałkowski, downy willow individuals were in a worse condition and they grew to a height of $45 \mathrm{~cm}$. The habitat was characterised by the absence of groundwater seepage, and the substrate $\mathrm{pH}$ was relatively low $(\mathrm{pH} 4.0)$.

The abovementioned downy willow stands on the Cow Marsh do not exist any more. The stands, unconfirmed in the years 2004-2005, had been located in the area which was later reclaimed and drained, where meadow ecosystems currently function and habitat conditions do not suit the preferences of the studied species.

Salix lapponum populations in areas which were and are now subjected to different forms of anthropopressure are few, and particular individuals are characterised by unsatisfactory condition and they do not produce inflorescence stems. It confirms the hypothesis that changes in habitat conditions in its stands are the main threat for downy willow (K r u s z elni cki, 2001), but it also indicates disorders in interpopulation processes. Therefore, it can be stated that small isolated populations of $S$. lapponum have a small chance of surviving in the habitats subjected to anthropopressure in the Łęczna-Włodawa Lakeland. Hence, it seems necessary to pursue twoway species conservation policy, involving chiefly population reconstruction by restitution, but also the inclusion of the peat bogs being the habitats of the boreal relic in area protection measures or covering them by ongoing monitoring. 


\section{Acknowledgements}

The author would like to thank warmly Ms. Katarzyna Kotlińska, M.A., and Mr. Piotr Stańko, M.A., for their invaluable assistance in carrying out field investigations.

\section{REFERENCES}

Fijałkowski D. 1958. Badania nad rozmieszczeniem i ekologią wierzby lapońskiej (Salix lapponum) na Pojezierzu Łęczyńsko-Włodawskim. / Studies on the distribution and ecology of downy willow (Salix lapponum) in the Łęczna-Włodawa Lakeland. Fragm. Floristica Geobot. $3(2), 89-103$

Fijałkowski D. 1959. Szata roślinna jezior i przylegających do nich torfowisk. / The vegetation cover of lakes in the Łęczna and Włodawa area and of peat bogs adjacent to these lakes. Ann. UMCS, sect. B, 14: 131-206.

Fijałkowski D, Izdebski K. 2002. Flora Poleskiego Parku Narodowego - Flora Naczyniowa. [In:] S. Radwan (ed.), Poleski Park Narodowy monografia przyrodnicza, 103-114, Wydawnictwo Morpol, Lublin, (in Polish).

Gajda J. 1997. Zmiany w składzie florystycznym łąk pobagiennych użytkowanych ekstensywnie na torfowisku Krowie Bagno. / Changes in the floristic composition of post-bog meadows used extensively on the peat bog Krowie Bagno. Zeszyty Problemowe Postępu Nauk Rolniczych: 453, 81-86

Kaźmierczakowa R., Zarzycki K. (ed.), 2001. Polska Czerwona Księga Roślin. Paprotniki i rośliny kwiatowe. Instytut Botaniki PAN, Kraków.

Kruszelnicki J. 2001. Wierzba lapońska (Salix lapponum L.) [In:] R. Kaźmierczakowa., K. Zarzycki (ed.), Polska Czerwona Księga Roślin. Paprotniki i rośliny kwiatowe. Instytut Botaniki PAN, Kraków (in Polish).

Mirek Z., Piękoś-Mirkowa H., Zając A., Zając M. 2002. Flowering plants and Pteridophytes of Poland. A checklist. Inst. Botaniki PAN, Kraków.

Pogorzelec M. 2008. The downy willow (Salix lapponum L.) population on the peat bog near Bikcze Lake (Łęczyńsko-Włodawskie Lakeland). Acta Agrobot. 61 (1): 91-97

Pogorzelec M. 2009. The downy willow (Salix lapponum L.) as a component of different phytocoenosis in Poleski National Park. Acta Agrobot. 62 (1): 107-116.

Popiołek Z. 1971. Roślinność wodna i przybrzeżna jezior okolic Ostrowa Lubelskiego. Wydawnictwo UMCS, Lublin.

Rutkowski L. 1998. Klucz do oznaczania roślin naczyniowych Polski niżowej. Wyd. Nauk. Państwowe Wydawnictwo Naukowe, Warszawa.

Radwan S., Kornijów R. 1998. Hydrobiologiczne cechy jezior - stan aktualny i kierunki zmian. [In:] M. Harasimiuk, Z. Michelczyk, M. Tuczyński (eds), Jeziora łęczyńsko-włodawskie. Wydawnictwo UMCS, Lublin (in Polish).

Radwan S. (red.), 1994. Środowisko przyrodnicze w strefie oddziaływania Kanału Wieprz-Krzna. Wydawnictwo TWWP, Lublin (in Polish).

Sołtys M., Różycki A. 1996. Rzadkie i zagrożone gatunki flory naczyniowej w Poleskim Parku Narodowym. [In:] S. Radwan (ed.), Funkcjonowanie ekosystemów wodno-błotnych w obszarach chronionych Polesia. Wydawnictwo UMCS, Lublin, 89-95 (in Polish).

Stamati K., Blackie S., Brown J. W. S., Russell J. 2003. A set of polymorphic SSR loci for subarctic willow (Salix lanata, S. lapponum and S. herbacea). Molecular Ecology Notes 3(2): 280-282.

Stamati K., Hollingsworth P.M. Russell J. 2007. Patterns of clonal diversity in three species of sub-arctic willow (Salix lonata, Salix lapponum and Salix herbacea). Plant Syst. Evol. 269: 75-88.

Sugier P. 2002. Dynamika roślinności wodnej i przybrzeżnej w północno-zachodniej części Pojezierza ŁęczyńskoWłodawskiego - rozprawa doktorska. Maszynopis w Zakładzie Ekologii Instytutu Biologii UMCS, Lublin (in Polish).

Wilgat T. 1991. Stosunki wodne Pojezierza Łęczyńsko-Włodawskiego. Zmiany stosunków wodnych pod wpływem gospodarki. [In:] A.S. Kleczkowski (ed.). Studia Ośrodka Dokumentacji Fizjograficznej, 19: 48-52, PAN, Wrocław, Warszawa, Kraków. (in Polish).

Zarzycki K., Trzcińska-Tacik H., Różański W., Szeląg Z., Wołek J., Korzeniak U. 2002. Ecological indicator values of vascular plants of Poland. W. Szafer Institute of Botany, Polish Academy of Science, Kraków

\section{Salix lapponum L. (wierzba lapońska) w stanowiskach poddanych antropopresji na Pojezierzu Łęczyńsko-Włodawskim}

\section{Streszczenie}

Celem badań przeprowadzonych w latach 2004-2005 i 2009 było poznanie warunków funkcjonowania roślinnego reliktu borealnego Salix lapponum w stanowiskach poddanych antropopresji na Pojezierzu Łęczyńsko-Włodawskim. Wyniki badań potwierdziły, że znacznie zmniejszyła się liczba stanowisk i liczebność oraz kondycja populacji wierzby lapońskiej nad jeziorem Miejskim i na Krowim Bagnie w okresie ostatnich 50. lat. Na podstawie analizy wyników badań czynników abiotycznych i biocenotycznych środowiska stwierdzono, że głównym zagrożeniem dla wierzby lapońskiej są zmiany warunków siedliskowych $\mathrm{w}$ jej stanowiskach. Innym powodem kurczenia się zasobów populacji oraz spadku kondycji osobników może być ich izolacja. Obserwowane zjawiska wewnątrzpopulacyjne tj. brak kwitnienia 
osobników oraz brak siewek wierzby lapońskiej, Niezbędnym wydaje się podjęcie próby czynnej ochromogą być przyczyną niedostatecznej efektywności ny gatunku, polegającej przede wszystkim na odbudorozmnażania, a co za tym idzie słabszego dostosowa- wie populacji przez restytucję. nia osobników do zmian warunków siedliskowych. 
